\title{
THE ISOLATION AND ELECTROPHORETIC CHARACTERIZATION OF THE PROTEINS IN THE URINE OF NORMAL SUBJECTS ${ }^{2}$
}

\author{
BY ELEANOR MCGARRY,2 ALEC H. SEHON, AND BRAM ROSE \\ (From the Allergy Research Division of the McGill University Clinic, Royal Victoria \\ Hospital, Montreal, Canada)
}

(Submitted for publication November 8, 1954; accepted February 9, 1955)

Studies of urinary proteins in disease characterized by proteinuria have been carried out by numerous investigators using a variety of techniques including electrophoresis (1-3). Although it is now generally conceded that protein is found in the urine of normal individuals (4), it is present in such small quantities as to escape detection by ordinary procedures. Except for the work of Rigas and Heller (5) a survey of the literature does not reveal any definitive data on the nature of the proteins found in the urine of normal individuals. These authors, on isolation and concentration of the high molecular weight material present in normal urine by ultrafiltration, reported that the material was electrophoretically separable into components the mobilities of which corresponded to those of albumin and of the various globulins usually found in serum.

Rigas and Heller (5) found the $A / G$ ratio in the urine of normal individuals to be 0.51 reflecting relative preponderance of globulins. They commented on the heterogeneity of globulin components and suggested it could have been acquired during the ultrafiltration process. The work reported here deals with an attempt to establish whether the low $A / G$ ratio and the heterogeneity of the globulins were artifacts of the method used by Rigas and Heller. Their method and other methods for concentrating proteins from dilute solutions were compared. For evaluation of the methods a dilute solution of normal serum in 0.9 per cent saline was used. The effect, if any, of a method of concentration on the electrophoretic pattern could thus be judged, using the pattern of the untreated serum as a standard.

The introduction of zone electrophoresis had

1 These studies were supported by a Grant from the United States Public Health Service, the Canadian National Research Council, and the Department of National Health and Welfare, Canada.

2 Senior Fellow of the Canadian National Research Council. made it possible to separate small amounts of protein mixtures into their electrophoretic components $(6,7)$. The method has been applied by Slater and Kunkel (3) to the characterization of proteins in pathological urine by paper electrophoresis. However, they reported inability to isolate and characterize proteins from normal urines. An attempt to identify the albumin found in normal urine with that of the serum is also reported here.

\section{MATERIALS AND METHODS}

All operations, unless otherwise stated, were carried out in a cold room, the temperature of which was $2^{\circ} \pm$ $1^{\circ} \mathrm{C}$. For evaluation of methods a dilute solution of normal serum was used $(1 \mathrm{ml}$. of serum per liter of saline) and this will be referred to as dilute serum in saline. Two liters of this solution were used for each determination.

When experiments with normal urines were undertaken a set of concurrent experiments was carried out on each of the following solutions :

(I) a dilute solution of serum proteins in saline as above,

(II) an aliquot of normal urine,

(III) a similar aliquot of the same normal urine to which was added $1 \mathrm{ml}$. of normal serum per liter.

In each set of experiments the same normal serum was used. Control sera were fresh pooled samples obtained through cooperation of the Blood Bank of the Royal Victoria Hospital. In all experiments the electrophoretic pattern of the untreated serum was independently determined by free electrophoresis.

Pooled urine specimens were collected at midday from young adult men and women working in the laboratories of the University Clinic. The subjects for the experiments on individual urines were all young adult men.

All urines were placed in the refrigerator immediately after voiding and were filtered as soon as possible. They were found free of protein by the conventional heat and acetic acid test. The final step in each method was the same: dilution, solution or suspension in veronal buffer to a volume of about $12 \mathrm{ml}$. and dialysis against veronal for at least 24 hours before electrophoretic analysis was carried out. After dialysis, using the refractive 
index of the buffer solution, "protein" concentration was calculated from the refractive index increment as measured with an Abbe refractometer (8). For consistency the same method was used for estimating the concentration of protein recovered from serum in saline solutions and from urine. In the latter instance it is considered only an approximation of the total protein content since one does not know the specific refractive index for urinary proteins or the contribution to the refractive index increments of non-protein high molecular weight material present in urine. In four instances the solution was recovered from the cell and, after dialysis against saline until the dialysate was found free of barbiturate, the protein nitrogen was measured chemically with a modified micro-Kjeldahl method and the protein calculated using the factor of 6.25. Barbiturate was measured by the method of Koppanyi, Murphy, and Krop (9) which is sensitive to $0.05 \mathrm{mg}$. per cent. Protein nitrogen was determined in duplicate on the precipitate formed by phosphotungstic acid.

Electrophoretic analysis: Because of the greater accuracy of free electrophoresis (classical Tiselius method) as compared to paper electrophoresis (10), the former technique was used for evaluation of methods of protein recovery. Free electrophoresis was carried out in an improved Tiselius apparatus ${ }^{3}$ in which a clearly defined pattern of serum proteins can be obtained with as little as 0.5 per cent protein solution. All experiments were carried out in veronal buffer of $\mathrm{pH} 8.6$ and ionic strength 0.1. In general, green monochromatic light (wavelength $=5,461 \AA$ ) was used; in some cases, when urines were deeply colored, a yellow filter had to be used. Conductivities were measured with an LKB bridge ${ }^{4}$ at $0^{\circ} \mathrm{C}$. Mobilities were calculated from the descending limb using the method of Longsworth and MacInnes (11). Using the method of calculation of Tiselius and Kabat (12) concentrations were obtained by planimetry of the areas of only the ascending pattern for consistency since in the descending pattern of normal sera per cent distribution could not be calculated because of the beta anomaly. It may be mentioned that in this laboratory only one fasting serum has failed to show the presence of the anomaly in over 500 analyses. Paper electrophoresis was done by the "horizontal strip" technique as modified in this laboratory (13).

Pervaporation: Concentration of dilute serum in saline solution by pervaporation was attempted. Five hundred $\mathrm{ml}$. aliquots were placed in dialysis tubing (Visking -3 in. wide) and hung at room temperature in a current of air produced by electric fans. After reduction in volume by about $100 \mathrm{ml}$, the bags were dialyzed against running tap water in order to prevent the concentration of salts as well as that of protein. These operations were done alternatively until the volume was reduced to about $50 \mathrm{ml}$. Final concentration to about 10 ml. was achieved by dialysis against dextran. Lyophyli-

${ }^{3}$ Spinco Model H, Specialized Instruments Corporation, Belmont, California.

4 Supplied by LKB Produckter, Stockholm, Sweden. zation was not attempted because it would have resulted in concentration of salts as well as proteins.

Dialysis against dextran: It was thought feasible to concentrate dilute protein solutions, concurrently removing water and salts, by dialysis against a concentrated aqueous solution of a high molecular weight material. Technical grade dextrans, which became available through the courtesy of various commercial firms were used for this purpose. A 25 per cent solution could readily be made with the dextran supplied by Commercial Solvents Corporation ${ }^{5}$ (average molecular weight 60,000 ) whereas the Swedish dextran ${ }^{\circ}$ with similar specifications was not as soluble. Three hundred to $350 \mathrm{ml}$. aliquots of serum in saline solution were placed in dialysis bags and dialyzed against dextran solution until the volume in each bag was about $30 \mathrm{ml}$. The contents of six bags were then pooled in one bag and dialysis against dextran continued until the volume was reduced to about $10 \mathrm{ml}$. Concentration of urine and urine plus serum was attempted on one occasion using Swedish dextran. During the long period of dialysis a good deal of small molecular weight dextran entered the bags so that the final volume could not be reduced below $30 \mathrm{ml}$.

Ammonium sulfate precipitation: Two attempts were made to apply the classical method of salting out with ammonium sulfate by saturating dilute serum in saline solution with the salt. Following precipitation the salts were removed by dialysis against running tap water and the precipitate was so finely divided that even centrifugation at $15,000 \mathrm{rpm}$. for 20 minutes did not result in a clear separation. Starting with 2 liters of serum in saline solution the procedure outlined above required at least two weeks. It was considered impractical and abandoned.

Ultrafiltration-Negative pressure: An apparatus such as is described by Dent (14) was used with the exception that bags were made from Visking dialysis tubing instead of collodion.

Ultrafiltration-Positive pressure: This method was used by Rigas and Heller in their experiments (5). For the present study an apparatus, such as is described by Gorbman (15), was built. A commercial model was also available and was used. It was deemed preferable to use membranes of constant pore size. Using unglazed cellophane, Visking cellulose membrane and Visking dialysis membrane and a pressure of 80 to $100 \mathrm{lbs}$. per sq. in., passage of distilled water was limited to a few $\mathrm{ml}$. per hour. With Gottingen "Ultrazellafilter" membranes distilled water passed through at a rate of about $100 \mathrm{ml}$. per hour. Distilled water passed through collodion membranes prepared in this laboratory at a rate of about 10 ml. per min. It was felt that elution of the protein from the membrane would be preferable to dissolution of the membrane. However, attempts at elution, using 0.9 per cent $\mathrm{NaCl}$ or veronal buffer of $\mathrm{pH} 8.6$ and ionic strength

\footnotetext{
5 Supplied through the courtesy of Commercial Solvents Corporation, Terre Haute, Indiana.

6 Supplied through the courtesy of Pharmacia, Uppsala, Sweden.
} 
of 0.1 were unsuccessful. An attempt to displace the protein by reversing the membrane and passing 0.9 per cent $\mathrm{NaCl}$ or veronal buffer through it under pressure also failed. Therefore it was necessary to dissolve the membranes even though the steps necessary were considered to be harsh treatment in view of the ease with which proteins are denatured. Collodion membranes were used and, after completion of filtration, were dissolved in alcohol-ether, washed three times with alcoholether, once with ether and dried. In the case of serum in saline, the precipitate was then dissolved in veronal buffer and dialyzed against veronal buffer before the electrophoretic analysis. The method of Rigas and Heller (5) prescribed the following additional steps when urine was used. The precipitate was extracted three times with $1.0 \mathrm{M}$ saline. The pooled supernatant fluid was dialyzed against water for twenty-four hours following which saturated saline solution was added $(2 \mathrm{ml}$. of saline for every $10 \mathrm{ml}$. of supernatant) and the proteins precipitated with 5 vol. of 94 per cent alcohol. Following centrifugation the precipitate was washed with absolute alcohol, once with anhydrous ether and dried before dissolving in veronal buffer.

Alcohol precipitation: Since repeated use of alcoholether solution was found necessary to recover proteins from the membranes after ultrafiltration, a step resulting in precipitation of the proteins as well as dissolution of the membrane, it was decided to precipitate the proteins directly with alcohol. One liter aliquots of a solution of serum in saline were placed in dialyzing jars which were packed in ice to bring down the temperature to $0^{\circ}$ C. Five volumes of 94 per cent ethyl alcohol were added slowly from a separatory funnel with constant stirring of the solution. Addition of the first liter at a rate greater than about 60 drops per min. resulted in a sharp rise in temperature to 8 to $10^{\circ} \mathrm{C}$. due to the heat of mixing. Addition of the alcohol at 50 to 60 drops a min. limited the temperature rise to 1 to $2^{\circ} \mathrm{C}$. After addition of the first liter the alcohol was added at the rate of about 600 $\mathrm{ml}$. per hr. Since no suitable refrigerated centrifuge to cope with such large volumes was available at the beginning of these experiments, the solution was left standing in the cold room until the precipitate was down and the supernatant clear. This usually occurred in 48 to 72 hours. The supernatant was then removed and the remainder transferred to a cylinder from which additional supernatant could be removed after 2 to 4 days. The precipitate was then centrifuged at $15,000 \mathrm{rpm}$. for 15 mins. in a Spinco Model $\mathrm{L}$ refrigerated ultracentrifuge. The precipitate was suspended in veronal.

Precipitates obtained by applying this method to urine, or to urine plus serum were too bulky to be dissolved in $12 \mathrm{ml}$. of veronal. At first they were suspended in distilled water (100 to $150 \mathrm{ml}$. being required) and dialyzed against distilled water. They were then dialyzed against saline in order to assure solution of any euglobulins which might have precipitated out. during dialysis against distilled water. The contents of the dialysis bag were centrifuged and the supernatant removed. To this were added 5 volumes of alcohol dropwise. The solu- tion was allowed to stand until the precipitate came down, usually 48 to 72 hours. The supernatant was suctioned off and the remainder spun down at $15,000 \mathrm{rpm}$. The precipitate was then suspended in veronal buffer.

Because of the bulk of the original precipitate it was felt that more efficient extraction of the protein from it might be obtained if the precipitate were suspended repeatedly in saline. Extractions were repeated until a negative test for protein was obtained with the heat and acetic acid test. This test is sensitive to $2 \mathrm{mg}$. per cent (16). Since 15 to $20 \mathrm{ml}$. of saline were used for each extraction subsequent to the second one, the amount of protein lost could not exceed, at the most, $0.4 \mathrm{mg}$. or less than 0.3 per cent of the total in any one experiment. The supernatants from each extraction, after centrifugation, were pooled and then dialyzed against saline for at least 48 hours with repeated changes of saline. In order to lessen the period of contact of protein with alcohol and to minimize the degree of denaturation while still maintaining the temperature of resultant mixture within reasonable limits, precooled alcohol was used. It was found that when alcohol, precooled to a temperature of $-40^{\circ} \mathrm{C}$., was added at about $100 \mathrm{ml}$. per min., the temperature of the mixture during addition of the first liter rose to $4^{\circ} \mathrm{C}$. The final temperature of the mixture after addition of 5 volumes of alcohol ranged from -10 to $-14^{\circ} \mathrm{C}$.

Ideally it would be desirable to centrifuge immediately after addition of alcohol, in the initial and final precipitation. Near the end of this study a more suitable refrigerated centrifuge (International PR2) became available and centrifugation immediately after the final addition of alcohol was carried out in the last 14 experiments and serum recoveries from saline were somewhat better. It was also done with the initial precipitations in the two final experiments. Final precipitates were completely soluble in veronal. It might be mentioned that the addition of precooled alcohol to a solution of serum in saline did not result in immediate precipitation of the proteins so that centrifugation had to be postponed for several days. However, precipitation became evident immediately after addition of precooled alcohol to urine and the supernatants after centrifugation remained completely clear indefinitely. Immediate centrifugation of the suspensions cut down the time required for the procedure from 3 to 4 weeks to 6 days.

For further support of the validity of this method for concentrating urinary proteins and for the identification of the component having the fastest electrophoretic mobility (which appeared to be that of albumin) the following experiments were done. An aliquot of $\mathrm{I}^{\text {1s1 }}$ tagged human serum albumin, ${ }^{7}$ representing 24 microcuries and $0.3 \mathrm{mg}$. of albumin, was added to each of the following: 2 liters of serum in saline solution, urine, and to urine plus serum solution and these three solutions were run through the procedure concurrently. The urine used represented, in each case, a 60-hour aliquot of a 5-day collection in one individual. The serum came from the

? Obtained from Abbott Laboratories. 
same pool of normal serum. Electrophoresis was done in the Tiselius apparatus and on paper. For paper electrophoresis a more concentrated protein solution is required than for free electrophoresis. Therefore, an amount of the veronal solution of the final precipitate, representing a 20-hour aliquot in the case of urine and an equivalent amount in the case of the serum in saline solution, was concentrated by dialysis against a 50 per cent solution of dextran 8 to a volume of about $0.25 \mathrm{ml}$. This concentrate was applied to paper, $0.01 \mathrm{ml}$. being used in the case of the urime concentrate, $0.006 \mathrm{ml}$. in the case of the serum in saline concentrate. . Electrophoresis was done at room temperature using 150 volts for 13 hours. The papers were stained with Amidoschwartz 10B, cut in $0.5 \mathrm{~cm}$. strips and each strip placed in a tube. Counting was done in a scintillation well counter consisting of a crystal of sodium iodide $11 / 2$ inches in diameter and 2 inches deep. Sensitivity of this counter is $8 \times 10^{5}$ counts per minute per microcurie and is essentially independent of volume so that activity in each strip was counted completely. After counting, the dye was eluted from each strip with a solution of 50 per cent methanol containing $5 \mathrm{ml}$. in $\mathrm{NaOH}$ per liter (17) and read in a Beckman Model B spectrophotometer at $600 \mathrm{~m} \mu$.

In an attempt to further identify the "albumin" found in urine with that of serum, $I^{121}$ tagged human serum albumin (IHSA) was injected intravenously into two normal individuals. The dose used in each case contained $1 \mathrm{mg}$. of albumin and 26 microcuries. Blood specimens were taken at 12 minutes, 24 and 48 hours after injection. Urine was collected for $\mathbf{4 8}$ hours. The concentrated urine proteins were characterized electrophoretically in the Tiselius apparatus and on paper. In view of the fact that the dose of IHSA was, of necessity, limited in human subjects, larger amount of protein had to be applied to paper. To achieve this the protein solution was concentrated by dialysis against 50 per cent dextran to about three times the protein concentration found in normal serum and $0.3 \mathrm{ml}$. of this solution was applied linearly with a pipette to three superimposed sheets of Whatman $3 \mathrm{~mm}$. filter paper $6 \%$ inches wide. The filter papers were supported on a sheet of plexiglass 7 inches wide and 14 inches long. The surface of the plexiglass was pebbled in a regular fashion with small trapezoid projections (6 to the square inch). The sheet of plexiglass with the papers were sandwiched between frames. These were enclosed between glass plates the inner surfaces of which were completely covered by sheets of Whatman $3 \mathrm{~mm}$. filter paper dipping into the buffer vessels. The buffer used was veronal and the ionic strength 0.05 , voltage was $160 \mathrm{~V}$, the current per strip was 2.5 to $3 \mathrm{~mA}$. The resulting bands were clearly and equally resolved on each of the three papers and did not show any deviation from linearity. The papers were cut into strips $0.5 \mathrm{~cm}$. wide. The protein curves were determined as before. $\mathrm{I}^{181}$ counts were done on 2 strips (i.e., $1 \mathrm{~cm}$.) at a time because of the small amount of IHSA present.

8 Provided through the courtesy of the R. K. Laros Company, Chemical Division, Bethlehem, Penna.

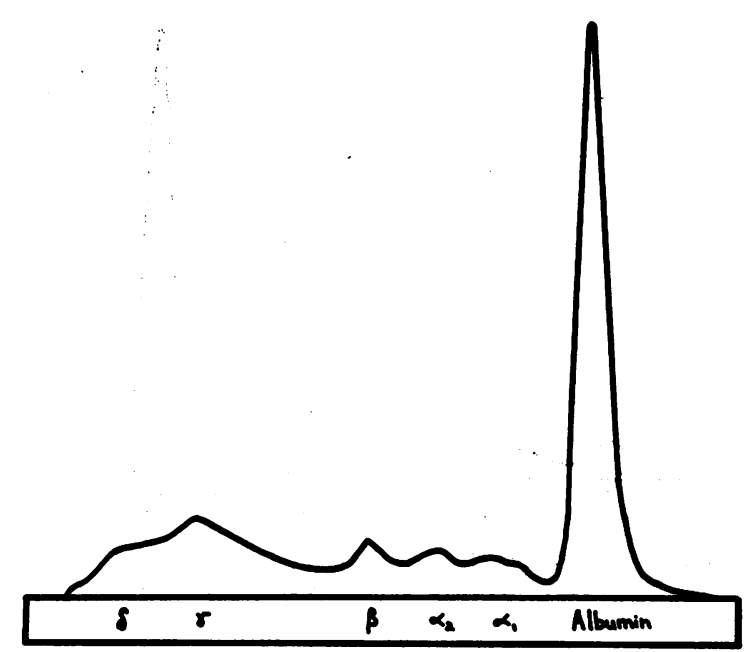

Fig. 1. Concentration of Serum in Saline Solution By Pervaporation

RESULTS

\section{Serum in saline}

Examples of typical electrophoretic patterns obtained by the various methods applied to the serum in saline solution may be seen in Figures 1 to 6 and compared with that of an untreated serum shown in Figure 7.

The Schlieren pattern obtained with pervaporation was not satisfactory. There was an additional peak in the region of alpha-1 and it was not possible, in either the ascending or descending limb, to clearly separate the gamma globulin peak from the sigma and epsilon anomalies (Figure 1).

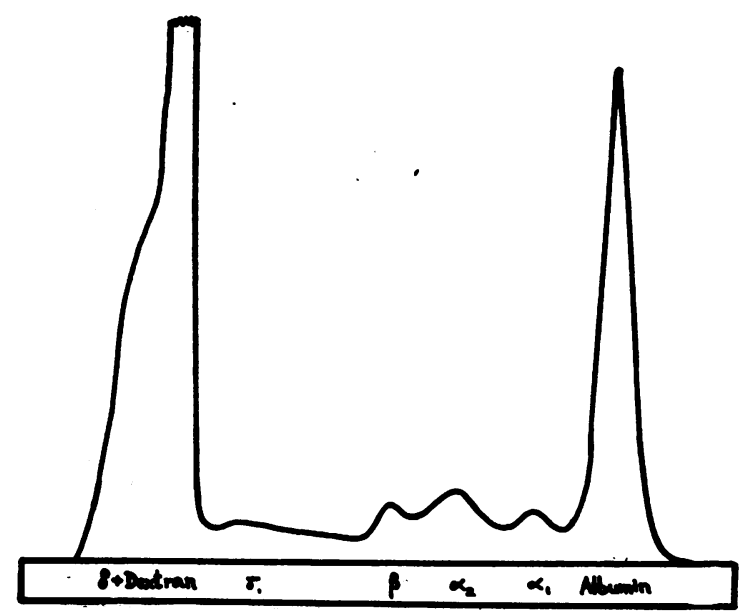

Fig. 2. Concentration of Serum in Saline Solution by Dialysis Against Dextran Solution 


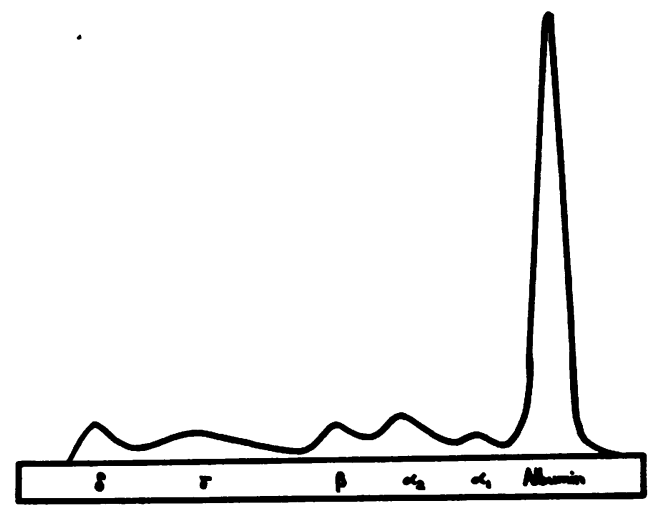

Fig. 3. Concentration of Serum in Saline Solution by Ultrafiltration with Negative Pressure

Concentration against dextran gave fairly good results on one occasion when technical grade dextran, supplied by Commercial Solvents Corporation, was used (Figure 2). With the Swedish dextran no individual globulin peaks could be de-

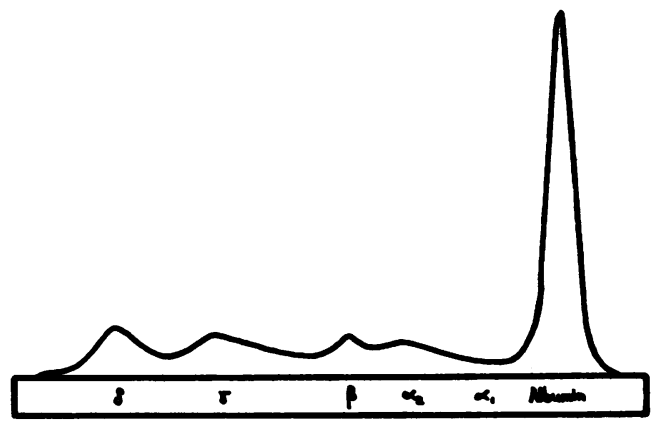

Fig. 4. Concentration of Serum in Saline Solution by. Ultrafiltration with Positive Pressure

lineated. In these and in other experiments with technical grade dextrans in this laboratory, regardless of the source of the polymer, some smaller molecular weight material diffused into the dialysis bag and appeared as an additional peak between

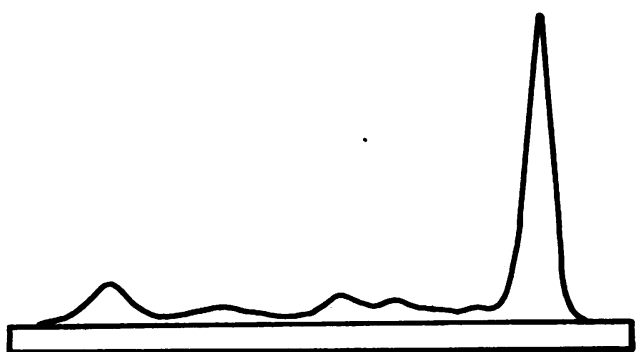

Fig. 5. Concentration of Serum in Saline Solution by a Single Prectpitation with Alcohol

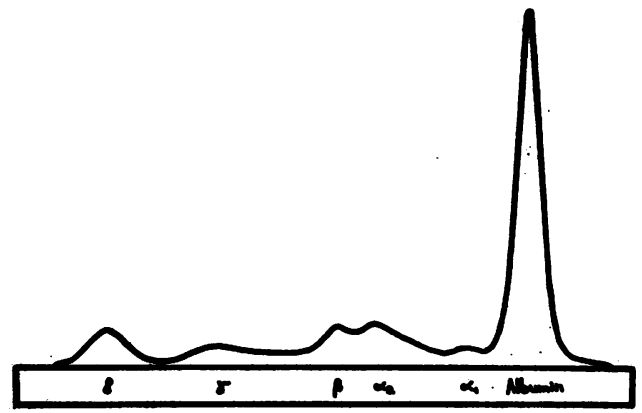

Fig. 6. Concentration of Serum in Saline Solution by Preciptration with Alcohol Followed BY Extraction with Saline and Further Prectpitation WITH Alcohol

the gamma and the delta and epsilon anomalies. In the experiment with the dextran supplied by Pharmacia this peak was exceedingly high.

Ultrafiltration by negative pressure gave good results (Figure 3 ). It required, however, 18 to 21 days to concentrate 2 liters of serum in saline solution by this method. The time required to concentrate a similar volume of urine would obviously be longer because of the greater solute content found in urine and, therefore, this method was considered impractical.

Ultrafiltration by positive pressure using collodion membranes was done using 2 liter aliquots of serum in saline solution (Figure 4). All fractions could usually be delineated by this method but quantitative deviations occurred from one experiment to another. For example, in some experiments the percentage of albumin was greater than in the original pattern, on other occasions it was less. The best recovery obtained by this method was 53.7 per cent. The average recovery

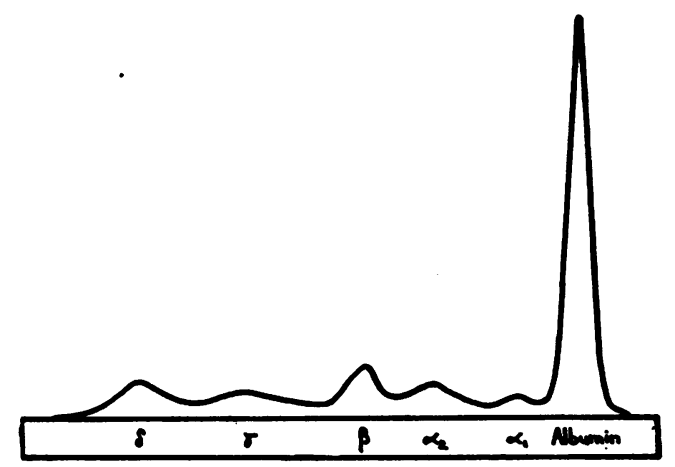

Fig. 7. Typical Curve for Control Serum 
TABLE I

Electrophoretically determined composition of untreated sera and of sera recovered from saline solution*

\begin{tabular}{|c|c|c|c|c|c|c|c|c|}
\hline Exp. No. & $\begin{array}{c}\% \\
\text { Proteint }\end{array}$ & $\begin{array}{c}\text { Albumin } \\
\%\end{array}$ & $\begin{array}{c}\text { Alpha } 1 \\
\%\end{array}$ & $\begin{array}{c}\text { Alpha } 2 \\
\%\end{array}$ & $\begin{array}{c}\text { Beta } \\
\%\end{array}$ & $\underset{\%}{\operatorname{Gamma}}$ & $\begin{array}{l}\mathbf{A} / \mathbf{G} \\
\text { ratioł }\end{array}$ & $\begin{array}{c}\% \\
\text { Recovery }\end{array}$ \\
\hline \multicolumn{9}{|c|}{ By alcohol precipitation at $0^{\circ} \mathrm{C}$. } \\
\hline $\begin{array}{l}\text { U.S. } 226 \\
\text { R.S. } 260\end{array}$ & $\begin{array}{l}0.90 \\
0.87\end{array}$ & $\begin{array}{l}56.01 \\
63.74\end{array}$ & $\begin{array}{l}5.23 \\
5.33\end{array}$ & $\begin{array}{r}10.96 \\
9.50\end{array}$ & $\begin{array}{r}13.47 \\
9.31\end{array}$ & $\begin{array}{l}14.32 \\
12.12\end{array}$ & $\begin{array}{l}1.27 \\
1.76\end{array}$ & 60.4 \\
\hline $\begin{array}{l}\text { U.S. } 293 \\
\text { R.S. } 310\end{array}$ & $\begin{array}{l}0.50 \\
0.54\end{array}$ & $\begin{array}{l}53.70 \\
68.36\end{array}$ & $\begin{array}{l}5.78 \\
4.93\end{array}$ & $\begin{array}{l}11.47 \\
12.34\end{array}$ & $\begin{array}{r}14.16 \\
4.69\end{array}$ & $\begin{array}{r}14.89 \\
9.67\end{array}$ & $\begin{array}{l}1.15 \\
2.16\end{array}$ & 48.9 \\
\hline $\begin{array}{l}\text { U.S. } 316 \\
\text { R.S. } 408\end{array}$ & $\begin{array}{l}0.94 \\
0.92\end{array}$ & $\begin{array}{l}57.02 \\
63.45\end{array}$ & $\begin{array}{l}4.85 \\
4.21\end{array}$ & $\begin{array}{r}11.26 \\
9.08\end{array}$ & $\begin{array}{l}13.97 \\
10.61\end{array}$ & $\begin{array}{l}12.90 \\
12.64\end{array}$ & $\begin{array}{l}1.33 \\
1.74\end{array}$ & 72.4 \\
\hline $\begin{array}{l}\text { U.S. } 404 \\
\text { R.S. } 430\end{array}$ & $\begin{array}{l}1.05 \\
0.94\end{array}$ & $\begin{array}{l}58.65 \\
63.90\end{array}$ & $\begin{array}{l}3.17 \\
3.68\end{array}$ & $\begin{array}{l}10.58 \\
10.52\end{array}$ & $\begin{array}{r}12.02 \\
8.45\end{array}$ & $\begin{array}{l}15.58 \\
13.44\end{array}$ & $\begin{array}{l}1.42 \\
1.77\end{array}$ & 69.7 \\
\hline $\begin{array}{l}\text { Average U.S. } \\
\text { Average R.S. }\end{array}$ & & $\begin{array}{l}56.50 \\
64.86\end{array}$ & $\begin{array}{l}4.76 \\
4.54\end{array}$ & $\begin{array}{l}11.07 \\
10.36\end{array}$ & $\begin{array}{r}13.41 \\
8.27\end{array}$ & $\begin{array}{l}14.42 \\
11.97\end{array}$ & $\begin{array}{l}1.30 \\
1.86\end{array}$ & 62.9 \\
\hline \multicolumn{9}{|c|}{ By alcohol precipitation at $-40^{\circ} \mathrm{C}$. and extraction } \\
\hline $\begin{array}{l}\text { U.S. } 404 \\
\text { R.S. } 448 \\
\text { R.S. } 487\end{array}$ & $\begin{array}{l}1.05 \\
0.66 \\
0.74\end{array}$ & $\begin{array}{l}58.65 \\
72.38 \\
57.21\end{array}$ & $\begin{array}{l}3.17 \\
3.15 \\
5.35\end{array}$ & $\begin{array}{r}10.58 \\
7.79 \\
20.88\end{array}$ & $\begin{array}{r}12.02 \\
8.52 \\
8.37\end{array}$ & $\begin{array}{r}15.58 \\
7.97 \\
8.18\end{array}$ & $\begin{array}{l}1.42 \\
2.62 \\
1.34\end{array}$ & $\begin{array}{l}46.8 \\
57.8\end{array}$ \\
\hline $\begin{array}{l}\text { U.S. } 512 \\
\text { R.S. } 490 \\
\text { R.S. } 523\end{array}$ & $\begin{array}{l}0.98 \\
1.03\end{array}$ & $\begin{array}{l}58.38 \\
62.26 \\
66.33\end{array}$ & $\begin{array}{l}3.90 \\
3.24 \\
4.54\end{array}$ & $\begin{array}{l}10.98 \\
14.59 \\
10.74\end{array}$ & $\begin{array}{r}11.85 \\
9.98 \\
8.65\end{array}$ & $\begin{array}{r}14.88 \\
9.92 \\
9.73\end{array}$ & $\begin{array}{l}1.4 \\
1.65 \\
1.97\end{array}$ & $\begin{array}{r}100.0 \\
70.0\end{array}$ \\
\hline $\begin{array}{l}\text { Average U.S. } \\
\text { Average R.S. }\end{array}$ & & $\begin{array}{l}58.52 \\
64.55\end{array}$ & $\begin{array}{l}3.54 \\
4.07\end{array}$ & $\begin{array}{l}10.78 \\
14.29\end{array}$ & $\begin{array}{r}11.94 \\
8.88\end{array}$ & $\begin{array}{r}15.23 \\
8.97\end{array}$ & $\begin{array}{l}1.41 \\
1.89\end{array}$ & 68.7 \\
\hline
\end{tabular}

* The electrophoretic pattern of each serum recovered from dilute saline solution (R.S.) is compared with the electrophoretic pattern of the original untreated serum (U.S.).

t Protein concentration in Tiselius cell.

$\$$ The A/G ratio for individual normal fasting sera in this'laboratory is $1.5 \pm 0.17$. The control sera in these experiments were pooled p.c. specimens.

on the last four experiments, when it was felt the technique was mastered, was 48.6 per cent.

\section{Alcohol precipitation}

This method gave the best recoveries of protein and the most consistent electrophoretic results. It was the only method by which all serum components in the dilute serum solution could be clearly and consistently separated. In general, there was an increased proportion of albumin in the pattern of the recovered serum when compared to that of the untreated serum, while there was a decrease in the beta and gamma globulins; the alpha globulins for the most part showed little change. Figure 5 illustrates the pattern obtained for recovered serum by a single alcohol precipitation of the protein followed by dissolution in veronal buffer. Figure 6, on the other hand, represents the pattern obtained when the initial precipitate was extracted with saline and reprecipitated with alcohol. These additional steps had been found necessary for the characterization of the urinary proteins. The relatively high albumin recovery by this method might be expected. In Cohn's method of plasma fractionation (18) al-

TABLE II

Electrophoretic composition of urine in normal individuals and urine + serum

\begin{tabular}{|c|c|c|c|c|c|c|}
\hline & \multirow{2}{*}{$\begin{array}{l}\text { Exp. } \\
\text { No. }\end{array}$} & \multirow[b]{2}{*}{ Albumin } & \multicolumn{3}{|c|}{ Globulins } & \multirow{2}{*}{$\begin{array}{l}\mathbf{A} / \mathbf{G} \\
\text { ratio }\end{array}$} \\
\hline & & & Alpha & Beta & Gamma & \\
\hline Average & $\left\{\begin{array}{l}449 \\
464 \\
489^{*} \\
524 \\
522 \\
558 \\
547\end{array}\right.$ & $\begin{array}{l}42.58 \\
32.13 \\
53.99 \\
39.74 \\
46.22 \\
40.30 \\
35.83 \\
39.13\end{array}$ & $\begin{array}{l}37.31 \\
46.91 \\
31.69 \\
42.28 \\
31.45 \\
37.73 \\
45.59 \\
40.21\end{array}$ & $\begin{array}{r}11.24 \\
9.19 \\
7.51 \\
11.47 \\
15.13 \\
14.20 \\
12.00 \\
12.21\end{array}$ & $\begin{array}{r}8.86 \\
11.76 \\
6.80 \\
6.51 \\
7.20 \\
7.77 \\
6.57 \\
8.11\end{array}$ & $\begin{array}{l}0.74 \\
0.37 \\
1.20^{*} \\
0.66 \\
0.86 \\
0.68 \\
0.56 \\
0.65\end{array}$ \\
\hline $\begin{array}{l}\text { Urine + } \\
\text { serum } \\
\text { Average }\end{array}$ & $\left\{\begin{array}{l}450 \\
488 \\
525 \\
519\end{array}\right.$ & $\begin{array}{l}\mathbf{5 8 . 4 2} \\
\mathbf{5 9 . 3 5} \\
\mathbf{5 6 . 5 6} \\
\mathbf{5 1 . 2 9} \\
\mathbf{5 4 . 2}\end{array}$ & $\begin{array}{l}27.67 \\
22.84 \\
28.90 \\
30.28 \\
28.5\end{array}$ & $\begin{array}{r}6.44 \\
10.06 \\
7.97 \\
8.19 \\
9.24\end{array}$ & $\begin{array}{r}7.46 \\
7.74 \\
6.56 \\
10.24 \\
8.03\end{array}$ & $\begin{array}{l}1.4 \\
1.46 \\
1.30 \\
1.05 \\
1.2\end{array}$ \\
\hline
\end{tabular}

\footnotetext{
* Not included in average, see Text.
} 


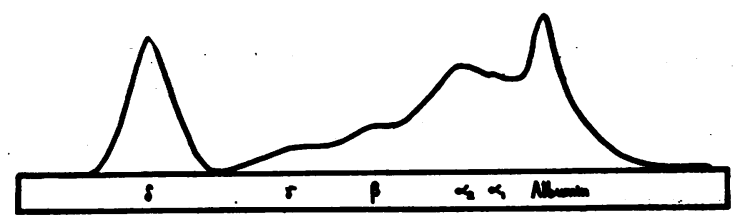

Fig. 8. Concentration of Nopual Urnis by Alcomol. Precipitation

bumin is the last component of the plasma proteins to be precipitated. Under the conditions of these experiments albumin appears to be the most soluble component. This was demonstrated in an experiment in which the pooled supernatants of the first three saline extractions were halved and to one were added the supernatants of the 4th and 5th extractions. Protein recovered by these additional extractions consisted mainly of alpha and beta globulin; it contained only 6.3 per cent albumin and 4.45 per cent gamma globulin. Table I summarizes the results of the alcohol precipitation method applied to the recovery of serum proteins from saline solutions.

\section{Urines}

The results obtained by applying the alcohol precipitation method to normal urine are presented in Table II. An example of the Schlieren patterns obtained with such concentrates of urine

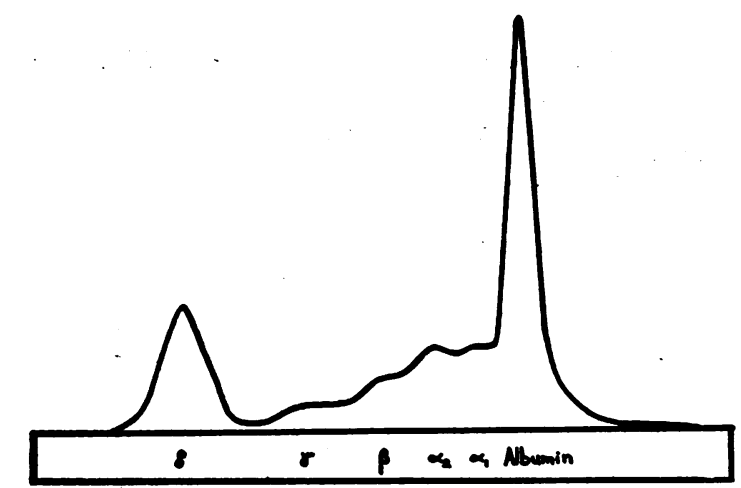

Fig. 9. Concrentration of Serum in Normal Urine by Alcohol Precipitation

and of the same urine to which normal serum had been added is shown in Figures 8 and 9 .

Electrophoretic mobilities of the various peaks in the Schlieren patterns of urines were of the same order of magnitude as the mobilities obtained in this laboratory for the recognized serum proteins (Table III). The significance of these data will be dealt with in the discussion. It may be pointed out, however, that the various components have been arbitrarily labelled as the ones conventionally found in serum.

It is evident that albumin makes up a smaller percentage of the protein found in urine as compared with serum proteins. The preponderant

TABLE III

Mobilities * of electrophoretically separable components found in the urine of normal individuals

\begin{tabular}{|c|c|c|c|c|c|c|}
\hline & \multirow[b]{2}{*}{ Exp. No. } & \multirow[b]{2}{*}{ Albumin } & \multicolumn{2}{|c|}{ Alpha } & \multicolumn{2}{|c|}{ Gamma } \\
\hline & & & Alpha 1 & Alpha 2 & Beta & Gamma \\
\hline & $\begin{array}{l}410 \\
431 \\
449 \\
464 \\
465 \\
489 \\
522 \\
524\end{array}$ & $\begin{array}{l}6.58 \\
6.50 \\
6.75 \\
6.70 \\
6.69 \\
6.62 \\
6.58 \\
6.58\end{array}$ & $\begin{array}{r}5.59 \\
5.39\end{array}$ & $\begin{array}{l}5.39 \\
4.96\end{array}$ & $\begin{array}{l}3.63 \\
3.45 \\
3.59 \\
3.60 \\
3.52 \\
3.80 \\
3.44 \\
3.62\end{array}$ & $\begin{array}{l}2.22 \\
2.27 \\
2.10 \\
2.37 \\
2.54 \\
2.43 \\
2.72 \\
2.39\end{array}$ \\
\hline & $\begin{array}{l}\text { Average } \\
\text { S.D. } \\
\text { Range }\end{array}$ & $\begin{array}{l}6.62 \\
\pm 0.08 \\
6.50-6.75\end{array}$ & \multicolumn{2}{|c|}{$\begin{array}{c}5.29 \\
\pm 0.21 \\
4.96-5.62\end{array}$} & $\begin{array}{c}3.58 \\
\pm 0.11 \\
3.44-3.80\end{array}$ & $\begin{array}{c}2.38 \\
\pm 0.19 \\
2.10-2.72\end{array}$ \\
\hline $\begin{array}{l}\text { Normalt } \\
\text { sera }\end{array}$ & $\begin{array}{l}\text { Average } \\
\text { S.D. } \\
\text { Range }\end{array}$ & $\begin{array}{l}6.73 \\
\pm 0.20 \\
6.43-7.18\end{array}$ & $\begin{array}{c}5.76 \\
\pm 0.18 \\
5.48-6.16\end{array}$ & 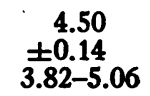 & $\begin{array}{c}3.54 \\
\pm 0.23 \\
3.22-4.03\end{array}$ & $\begin{array}{c}1.67 \\
\pm 0.18 \\
1.42-2.01\end{array}$ \\
\hline
\end{tabular}

* These values have been divided by $10^{-6} \mathrm{~cm} .^{2}$ per sec. per volt.

$\dagger$ These values are given for comparison; they are based on experiments of untreated fasting sera obtained from 14 normal subjects.

$¥$ The mobilities are slightly higher than those conventionally quoted (19). They were observed at a serum protein concentration of only 0.5 to 1 per cent. These results are in agreement with the findings of Lippman and Banovitz (20). 
globulins are those having a mobility distribution similar to that of the alpha globulins of serum. This confirms the findings of Rigas and Heller (5).

The A/G ratio was found to be, with one exception, Exp. No. 489, Table II, less than one; with an average of 0.65 compared to an average of 1.5 in serum (by the electrophoretic method). Two individuals with urinary $A / G$ ratios greater than unity were found in the study by Rigas and Heller (5) to have orthostatic albuminuria. In the present study evidence of the existence of orthostatic albuminuria was looked for but was not obtained; no albuminuria was present in this subject after activity. However, the results of the experiments with the urine of this subject were not included in the calculation of the averages.

The amount of protein found in the urine averaged $70.9 \mathrm{mg}$. per day when measured refractometrically. Four chemical determinations of protein concentration gave values ranging from 6.9 per cent to 12.3 per cent (average 10.1 per cent) lower than those obtained refractometrically.

The results of the experiments in which $I^{131}$ tagged human serum albumin was added to serum in saline, to urine and to urine plus serum are shown in Figure 10. The $\mathrm{I}^{181}$ peak is confined to an area which corresponds with the albumin peak of the protein curve. It may be seen that the $I^{181}$ peak is slightly ahead of the albumin peak in agreement with the recent report of Gabrieli, Goulian, Kinersly, and Collet (21). Figure 10 also demonstrates that the result obtained when urinary proteins. are separated by electrophoresis on paper is similar to that obtained with free electrophoresis. The amount of protein applied to the paper in this instance represents 1.3 per cent of the total recovered from a 60 -hour urine specimen, that is, the amount excreted in 50 minutes.

When $\mathrm{I}^{131}$ tagged human serum albumin was injected intravenously into two normal human subjects the dose was limited to 26 microcuries and the amount of tagged albumin excreted was correspondingly small. One $\mathrm{cm}$. strips were counted for 10 minutes. Counts from regions other than the albumin area gave values below background. The increments in count of the
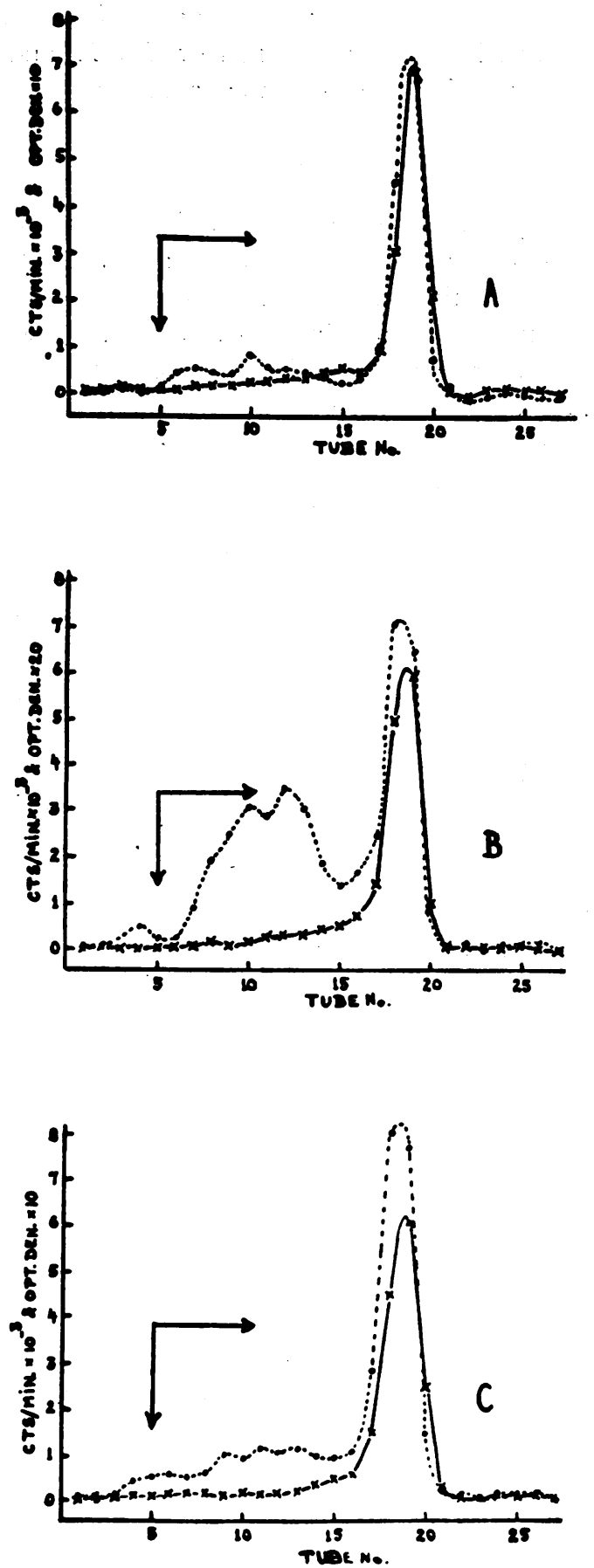

FIG. 10

Crosses represent $I^{100}$ counts and circles represent optical densities. Curves $A$ refer to concentration of serum in saline solution containing Im-HSA. Curves $B$ refer to concentration of urine containing Im-HSA. Curves $C$ refer to concentration of serum in urine containing $I^{m}$. HSA. 
strips corresponding to the area of albumin amounted in one experiment to $525 \pm 77$ and in the other to $520 \pm 78$ counts per minute.

\section{DISCUSSION}

Except in ultrafiltration experiments, followed by dissolution of the membrane, all material recovered by the other method from dilute serum solutions was soluble in veronal buffer. The experiments reported here indicate that all the techniques applied for concentrating serum proteins from dilute solutions produced some loss of definition of the electrophoretic pattern and resulted in some small change in the relative amounts of the various protein components. This suggests that the alteration in the Schlieren pattern might be attributed to some denaturation of the proteins on dilution, a well-known phenomenon in protein chemistry. Another common feature of all methods is a lower recovery of the globulin component. The beta anomaly, almost invariably present in the descending patterns of human serum in free electrophoresis, was absent in the recovered sera by all methods except by concentration by ultrafiltration under negative pressure and dialysis against dextran; with these methods the beta anomaly was detectable but not prominent. Most of the lipoproteins in serum migrate with the beta globulin. It is accepted that lipoproteins are highly unstable and the low recoveries of globulin, in these experiments regardless of method used, may well be due to the splitting of the lipoprotein bond on dilution of the serum in saline. In spite of this it is felt that the dilute solution of serum used in these experiments fulfills the conditions of a reliable standard for evaluating various methods of concentration of proteins in urine.

Concentration by alternate pervaporation and dialysis resulted in poor resolution. It may be that dialysis against water was not done frequently enough and, at times, the concentration of salts rose to an undesirable level. It is probable that this may also account for the failure of Slater and Kunkel to characterize proteins in normal urine following concentration by lyophylization (3).

During concentration by dialysis against dextran, salts as well as water were removed. At the same time, however, some of the smaller molecular weight dextrans present in the batches used entered the dialysis bag. This prevented the concentration process from proceeding to the extent required for electrophoretic experiments. At the time of these experiments no dextrans of a more homogeneous molecular weight distribution (ca. 40,000 ) were available. It was impossible to concentrate the urines without preventing diffusion of the smaller molecular weight dextrans into the urine solutions. Further experiments were therefore abandoned. In principle, however, there is no reason why concentration of urine by dialysis against a concentrated aqueous solution of an adequate polyelectrolyte should not yield satisfactory results. As a matter of fact, towards the end of this study dextrans of a more homogeneous molecular weight distribution became available. ${ }^{\circ}$ With a 30 to 50 per cent solution of these dextrans dilute protein solutions can be almost completely dehydrated. These dextrans were used for concentrating the solutions recovered from the Tiselius cell prior to application to paper in the $I^{181}$ studies.

Ultrafiltration by positive pressure did not prove satisfactory in our hands. The pore size of collodion membranes almost certainly varies from one membrane to another. It is conceivable that on occasion smaller protein molecules may escape through the membrane. This may account for the comparatively low A/G ratio for recovered serum proteins of 1.21 obtained with this method.

It has been demonstrated that passage of urine through a membrane decreases its permeability to water (15). This blocking effect is greater with urines containing readily demonstrable protein. Apparently protein adheres to the interstices of the membrane. We were unable to elute the proteins from the membrane by washing with saline or veronal buffer or by reverse flow under pressure. To recover the proteins the membrane was dissolved in alcohol-ether solution, which is considered to be drastic treatment for proteins in general. Additional steps necessary to recover proteins from urine required further precipitation of the proteins with alcohol (5). It seemed logi-

9 Provided through the courtesy of L. K. Laros Company, Chemical Division, Bethlehem, Penna. (Batch No. IV-370-361-372, mol. wt. 74,000; 10 per cent low fraction of mol. wt. 30,100) and the Dextran Corporation, Yonkers, N. Y. (Batch No. 2058, average mol. wt. 58,800 ). 
TABLE IV

Electrophoretic mobilities * of serum proteins recovered from saline

\begin{tabular}{|c|c|c|c|c|c|c|c|}
\hline & \multirow[b]{2}{*}{ Exp. No. } & \multirow[b]{2}{*}{ Albumin } & \multicolumn{4}{|c|}{ Globulins } & \\
\hline & & & Alpha 1 & Alpha 2 & Beta & Gamma & \\
\hline & $\begin{array}{l}408 \\
448 \\
463 \\
487 \\
490 \\
515 \\
523\end{array}$ & $\begin{array}{l}6.84 \\
6.65 \\
6.81 \\
6.58 \\
6.49 \\
6.67 \\
6.58\end{array}$ & $\begin{array}{l}\mathbf{5 . 8 0} \\
\mathbf{5 . 5 7} \\
\mathbf{5 . 8 3} \\
\mathbf{5 . 7 1} \\
\mathbf{5 . 6 0} \\
\mathbf{5 . 7 2} \\
\mathbf{5 . 6 0}\end{array}$ & $\begin{array}{l}4.43 \\
4.34 \\
4.93 \\
3.93 \\
3.99 \\
4.03 \\
4.35\end{array}$ & $\begin{array}{l}\mathbf{3 . 7 2} \\
\mathbf{3 . 4 8} \\
\mathbf{3 . 6 6} \\
\mathbf{3 . 6 2} \\
\mathbf{3 . 6 2} \\
\mathbf{3 . 5 1} \\
\mathbf{3 . 5 9}\end{array}$ & $\begin{array}{l}1.67 \\
1.75 \\
1.68 \\
1.72 \\
1.86 \\
1.69 \\
1.86\end{array}$ & . \\
\hline & $\begin{array}{l}\text { Average } \\
\text { S.D. } \\
\text { Range }\end{array}$ & $\begin{array}{c}\quad 6.66 \\
\pm 0.12 \\
6.49-6.84\end{array}$ & $\begin{array}{c}5.69 \\
\pm 0.10 \\
5.57-5.83\end{array}$ & $\begin{array}{c}4.29 \\
\pm 0.34 \\
3.93-4.43\end{array}$ & $\begin{array}{c}3.60 \\
\pm 0.08 \\
3.48-3.72\end{array}$ & $\begin{array}{c}1.74 \\
\pm 0.08 \\
1.67-1.86\end{array}$ & \\
\hline $\begin{array}{l}\text { Normal } † \\
\text { sera }\end{array}$ & $\begin{array}{l}\text { Averageł } \\
\text { S.D. } \\
\text { Range }\end{array}$ & $\begin{array}{c}6.73 \\
\pm 0.20 \\
6.43-7.18\end{array}$ & $\begin{array}{c}5.76 \\
\pm 0.18 \\
5.48-6.16\end{array}$ & $\begin{array}{c}4.50 \\
\pm 0.14 \\
3.82-5.06\end{array}$ & $\begin{array}{c}3.54 \\
\pm 0.23 \\
3.22-4.03\end{array}$ & $\begin{array}{c}1.67 \\
\pm 0.18 \\
1.43-2.01\end{array}$ & \\
\hline
\end{tabular}

* These values have been divided by $10^{-6} \mathrm{~cm}^{2}$ per sec. per volt.

T These values are given for comparison; they are based on experiments of untreated fasting sera obtained from 14 normal subjects.

‡ The mobilities are slightly higher than those conventionally quoted (19). They were observed at a serum protein concentration of only 0.5 to 1 per cent. These results are in agreement with the findings of Lippman and Banovitz (20).

cal, therefore, to precipitate the proteins directly with alcohol.

The alcohol precipitation method gave the most consistent results and the best recoveries of serum proteins from dilute solutions. It is not ideal. There was always some loss of definition of the globulin peaks in the Schlieren pattern. The method favours the recovery of albumin. The A/G ratio of serum recovered from saline solution was always higher than that found in untreated sera. Nevertheless, it is to be noted that electrophoretic mobilities of the various components in the recovered sera closely approximated the normal values (Table IV) which is considered strong support in favour of this method of concentration. Experiments at different $\mathrm{pH}$ and ionic strength might give more satisfactory results.

Schlieren diagrams obtained when the alcohol precipitation method was applied to urine showed poor resolution. Peaks of the slower moving components are superimposed on a continuous broad curve. The area under any one peak in the globulin region is somewhat arbitrarily delineated and its measurement and the per cent composition derived from it are at best only an approximation. The Schlieren diagrams presented in the paper by Rigas and Heller (5) reveal a similar loss of definition of the globulins in normal urines. However, the albumin peak in both studies is relatively well-separated from the globulins and the $A / G$ ratio can be obtained with a fair degree of accuracy. When the ultrafiltration method was applied to serum in saline in this laboratory the $A / G$ ratio of the recovered proteins was found to be 1.21 compared to 1.75 found with the alcohol precipitation method. The electrophoretically determined $A / G$ ratio of the untreated sera used in these experiments was 1.36. It is not surprising, therefore, that the $A / G$ ratio of 0.65 found in this study is slightly higher than that of 0.51 reported by Rigas and Heller. ${ }^{10}$ Nonetheless, the results of these authors showing a reversed $A / G$ ratio in normal urines as compared to that found in normal sera are confirmed by the present experiments.

In spite of poor delineation of the Schlieren pattern electrophoretic mobilities of the components found in urine are remarkably reproducible (Table III). The mobilities of albumin and of globulins labelled alpha and beta in urine are of the same order of magnitude as of their counterparts in serum. However, the peak between beta globulin and the delta and epsilon anomalies, respec-

10 Since the submission of the present paper for publication, Boyce, Garvey, and Norfleet (22) have reported that using the method of Rigas and Heller they obtained a value of 0.65 for the $A / G$ ratio in normal urines, which is identical to our value. They also stated that the average amount of colloids excreted per 24 hours was 86 to $97 \mathrm{mg}$. which is in excellent agreement with the values of $90 \mathrm{mg}$. derived in the present report. 
tively, labelled as gamma globulin, has a higher mobility than that of gamma globulin in serum. The predominant globulins in normal urine are those having a mobility similar to the alpha globulins of serum.

In both ascending and descending patterns there was a marked increase in the size of the delta and epsilon anomalies, respectively. Rigas and Heller found (5) this to be due to a high molecular weight polysaccharide. These authors also reported (5) an unidentified component migrating more rapidly than albumin which they designated $X$. Similarly, in all the urine experiments in the present study there was some material with a greater mobility than that of albumin. This was seen as a small peak in the initial stages of the electrophoretic resolution but became ill defined in the final pattern probably due to diffusion. No attempt was made to further characterize this or the material contributing to the enlargement of the delta and epsilon peaks. It might be mentioned that in the electrophoretic analysis of cerebrospinal fluid proteins a small peak occurs ahead of the albumin (23).

Such a peak is also found in this laboratory when serum proteins are separated by zone electrophoresis using starch as a supporting medium. Similarly, it has been reported to be present in certain abnormal sera in free electrophoresis (24).

Calculation of total protein concentration of urine from the refractive index increment can only give an approximation as has already been pointed out. Total protein content based on nitrogen determination was found to be 10 per cent lower than that found by refractive index measurements. The data reported here by either method are too meager to draw many conclusions.

For convenience, in this study actual figures have been used to express recoveries, composition, and mobilities. These absolute values must be considered with caution.

Thus, the techniques employed have qualitative and quantitative limitations and the results of the experiments on urines can only be interpreted accordingly. Within this frame of reference they are believed to be valid.

A survey of the literature does not reveal any recent direct determination of the daily output of proteins in the urine of normal individuals. The results of Mörner (25) led to a value of 25 to 89 mg. per liter. Rigas and Heller state the average daily output to be $39 \mathrm{mg}$. (5) as calculated from their electrophoretic patterns. Unfortunately, it is not possible to derive from their published data what their per cent recovery was. The results of the present study, using the alcohol method show the average daily output to be $71 \mathrm{mg}$. This may be considered the lower limit since the experiments with dilute saline solution gave only an average recovery of 70 per cent. Assuming that the per cent recovery from urines was of the same order, it would seem probable that the actual value for the average daily output could be as high as 90 mg. based on nitrogen determination.

While the absolute amounts of the protein components recovered when serum is added to urine may be questioned, examination of the Schlieren diagrams of these experiments shows that neither the heterogeneity nor the preponderance of globulins in normal urine can be attributed to the limitations of the method.

The $I^{131}$ studies support the thesis that the albumin found in urine is identical with that of plasma, in fact it is, in part at least, serum albumin.

Assuming all the proteins found in urine are serum proteins filtered through the glomerular membrane, the relatively low albumin concentration can be readily explained by tubular reabsorption (4). There is no absolute evidence, however, that all of the albumin and the globulins found in normal urine are derived solely from serum proteins. Immunological studies and further isotope studies with labelled serum proteins other than albumin would help to clarify the situation.

It is conceivable that some of the protein found in normal urine could be contributed by breakdown of cells shed from the genito-urinary tract.

It is equally possible that the Schlieren pattern which appears to be characteristic of urine in normal individuals may be the result of interaction between the proteins present and other high molecular weight material known to be present in urine. Rigas and Heller suggest as a possible explanation for the heterogeneity of the patterns the "co-existence of proteins with intermediateelectrophoretic mobilities which are either absent from serum or present in very small amounts" (5). This would imply relative failure of reabsorption or tubular secretion of these moieties. 
The few experiments using paper electrophoresis have shown that this simpler and cheaper method of analysis could be fruitfully applied to evaluation of the protein pattern in urines. The advantage of this method over free electrophoresis is that it requires much smaller aliquots of urine. On one occasion a 12-hour aliquot proved to be adequate. It also enables one to localize isotope tagged protein fractions and could be used to differentiate the glyco and lipoprotein moieties, in urine.

\section{SUM MARY}

Methods for concentrating proteins from dilute solutions are described and their limitations are discussed. Alcohol precipitation was found to give the best recoveries and the most consistent results. The proteins in the urine of normal subjects, isolated by the alcohol precipitation method, were characterized by free electrophoresis. Protein components were found in urine having mobilities of the same order of magnitude as albumin and globulins of serum. The preponderant globulins of urine were those having an electrophoretic mobility similar to that of the alpha globulins of serum. Globulin components showed marked heterogeneity. The $A / G$ ratio was found to be 0.65. An unidentified moiety with a mobility greater than that of albumin was found to be present in urine. The average protein output in the urine of normal individuals would appear to be at least $71 \mathrm{mg}$. a day, a figure somewhat higher than previously reported. Experiments with $I^{131}$ tagged human serum albumin in two normal subjects showed that serum albumin is excreted in the urine of normal individuals. Some experiments using paper electrophoresis demonstrated that this method may be applied to the study of electrophoretic pattern of proteins in relatively small aliquots of normal urine.

\section{ACKNOWLEDGMENTS}

We wish to acknowledge the technical assistance of Mrs. A. Elovic and Mr. E. R. deVries. We should like to acknowledge the assistance and advice of Drs. C. B. Pierce and L. G. Stephens-Newsham of the Dept. of Radiology, Royal Victoria Hospital, Montreal, in connection with the isotope studies.

\section{REFERENCES}

1. Luetscher, J. A., Jr., Electrophoretic analysis of plasma and urinary proteins. J. Clin. Invest., 1940, 19, 313.

2. Longsworth, L. G., and MacInnes, D. A., An electrophoretic study of nephrotic sera and urine. J. Exper. Med., 1940, 71, 77.

3. Slater, R. J., and Kunkel, H. G., Filter paper electrophoresis with special reference to urinary proteins. J. Lab. \& Clin. Med., 1953, 41, 619.

4. Rather, L. J., Filtration, resorption and excretion of protein by the kidney. Medicine, 1952, 31, 357.

5. Rigas, D. A., and Heller, C. G., The amount and nature of urinary proteins in normal human subjects. J. Clin. Invest., 1951, 30, 853.

6. Durrum, E. L., A microelectrophoretic technique and microionophoretic technique. J. Am. Chem. Soc., 1950, 72, 2943.

7. Kunkel, H. G., and Tiselius, A., Electrophoresis of proteins on filter paper. J. Gen. Physiol., 1951, 35, 89.

8. Armstrong, S. H., Jr., Budka, M. J. E., Morrison, K. C., and Hasson, M., Preparation and properties of serum and plasma proteins. XII. The refractive properties of the proteins of human plasma and certain purified fractions. J. Am. Chem. Soc., 1947, 69, 1747.

9. Koppanyi, T., Murphy, W. S., and Krop, S., Colorimetric detection of barbital and its applications. Proc. Soc. Exper. Biol. \& Med., 1933, 30, 542.

10. Köiw, E., Wallenius, G., and Grönwall, A., Paper electrophoresis in clinical chemistry; a comparison with Tiselius' original method. Scandinav. J. Clin. \& Lab. Invest., 1952, 4, 47.

11. Longsworth, L. G., and MacInnes, D. A., The interpretation of simple electrophoretic patterns. J. Am. Chem. Soc., 1940, 62, 705.

12. Tiselius, A., and Kabat, E. A., An electrophoretic study of immune sera and purified antibody preparations. J. Exper. Med., 1939, 69, 119.

13. Grassmann, W., and Hannig, K., Ein quantitatives Verfahren zur Analyse der Serumproteine durch Papierelektrophorese. Hoppe Seyler's Ztschr. f. physiol. Chem., 1952, 290, 1.

14. Dent, C. E., Paper chromatography and medicine in Recent Advances in Clinical Pathology. S. C. Dyke, ed., 2nd ed., London, J. \& A. Churchill, 1951, p. 238.

15. Gorbman, A., Ultrafiltration of urine for collection and biological assay of excreted hypophyseal hormones. Endocrinology, 1945, 37, 177.

16. Ham, T. H., ed., A Syllabus of Laboratory Examinations in Clinical Diagnosis; Cortical Evaluation of Laboratory Procedures in the Study of the Patient. Cambridge, Mass., Harvard Univ. Press, 1950, p. 496.

17. Pučar, Z., Utber die Färbung der Papier-Elektropherogamme mit Amidoschwartz. Hoppe Seyler's Ztschr. f. physiol. Chem., 1954, 296, 62. 
18. Cohn, E. J., Strong, L. E., Hughes, W. L., Jr., Mulford, D. J., Ashworth, J. N., Melin, M., and Taylor, H. L., Preparation and properties of serum and plasma proteins. IV. A system for the separation into fractions of the protein and lipoprotein components of biological tissues aad fluids. J. Am. Chem. Soc., 1946, 68, 459.

19. Dole, V. P., The electrophoretic patterns of normal plasma. J. Clin. Invest., 1944, 23, 708.

20. Lippman, R. W., and Banovitz, J., The influence of protein concentration upon electrophoretic mobility of serum proteins. J. Biol. Chem., 1952, 199, 451.

21. Gabrieli, E. R., Goulian, D., Jr., Kinersly, T., and Collet, R., Zone paper electrophoresis studies on radio-iodinated human serum albumin. J. Clin. Invest., 1954, 33, 136.
22. Boyce, W. H., Garvey, F. K., and Norfleet, C. M., Jr., Proteins and other biocolloids of urine in health and in calculous disease. I. Electrophoretic studies at $\mathrm{pH} 4.5$ and 8.6 of those components soluble in molar sodium chloride. J. Clin. Invest., 1954, $33,1287$.

23. Hoch, H., and Chanutin, A., Electrophoretic studies on cerebrospinal fluid. Proc. Soc. Exper. Biol. \& Med., 1952, 81, 628.

24. Hoch, H., and Chanutin, A., Electrophoretic studies on fast moving components of human serum. J. Biol. Chem., 1953, 200, 241.

25. Mörner, K. A. H., Untersuchungen über die Proteinstoffe und die eiweissfällenden Substanzen des normalen Menschenharns. Skandinav. Arch. f. Physiol., 1895, 6, 332. 